\title{
Review : Medication Erorr Pada Tahap Prescribing, Transcribing, Dispensing, dan Administration
}

\author{
M. A. W. Khairurrijal*, Norisca Aliza Putriana \\ Program Profesi Apoteker, Fakultas Farmasi, Universitas Padjadjaran, Sumedang, 45363 \\ email: khairurr11@gmail.com
}

\section{Abstrak :}

Medication error adalah suatu kejadian yang tidak hanya dapat merugikan pasien tetapi juga dapat membahayakan keselamatan pasien yang dilakukan oleh petugas kesehatan khususnya dalam hal pelayanan pengobatan pasien yang sebetulnya dapat dicegah. Medication error dapat terjadi pada tahapan prescribing, transcribing, dispensing, dan administering. Dalam review jurnal ini, tahap teradinya masalah medication error dikumpulkan dan diulas kembali untuk melihat faktor-faktor yang mempengaruhi medication error, prevalensinya, serta peran Apoteker dalam pencegahan terjadinya kesalahan pengobatan (medication error).

Keyword : Medication error, prescribing, transcribing, dispensing, administering

\section{Pendahuluan}

Pelayanan kefarmasian merupakan suatu pelayanan langsung dan bertanggungjawab kepada pasien yang berkaitan dengan sediaan farmasi dengan maksud mencapai hasil yang pasti untuk meningkatkan mutu kehidupan pasien. Salah satu tujuan pelayanan kefarmasian yaitu melindungi pasien dan masyarakat dari penggunaan obat yang tidak rasional dalam rangka keselamatan pasien (patient safety) (PMK RI No 58,2014 ).

Keselamatan pasien merupakan suatu disiplin baru dalam pelayanan kesehatan yang mengutamakan pelaporan, analisis, dan pencegahan medical error yang sering menimbulkan Kejadian Tak Diharapkan (KTD) dalam pelayanan kesehatan. Kegiatan skrining resep yang dilakukan tenaga kefarmasian untuk mencegah terjadinya keselahan pengobatan (Medication error) (Depkes RI, 2008). Medical error adalah kejadian yang merugikan pasien akibat pemakaian obat selama dalam penanganan tenaga kesehatan yang sebetulnya dapat dicegah (KepMenKes No 1027, 2004).

Medical error merupakan kejadian yang menyebabkan atau berakibat pada pelayanan kesehatan yang tidak tepat atau membahayakan pasien yang sebenarnya dapat dihindari. Konsep medication safety mulai menjadi perhatian dunia sejak November 1999 setelah Institute of Medication (IOM) melaporkan adanya kejadian yang tidak diharapkan (KTD) pada pasien rawat inap di Amerika sebanyak 44.000 bahkan 98.000 orang meninggal karena medical error (kesalahan dalam pelayanan medis) dan 7.000 kasus karena medication error (ME). Terjadi atau tidaknya suatu kesalahan dalam pelayanan pengobatan terhadap pasien telah menjadi indikator penting dalam keselamatan pasien. Medication error merupakan jenis medical error yang paling sering dan banyak terjadi (Kohn L et al., 2000). 
Kesalahan pengobatan (medication error) dapat terjadi pada 4 fase, yaitu kesalahan peresepan (prescribing error), kesalahan penerjemahan resep (transcribing erorr), kesalahan menyiapkan dan meracik obat (dispensing erorr), dan kesalahan penyerahan obat kepada pasien (administration error) (Adrini TM, 2015).

Secara umum, faktor yang paling sering mempengaruhi medication error adalah faktor individu, berupa persoalan pribadi, pengetahuan tentang obat yang kurang memadai, dan kesalahan perhitungan dosis obat (Mansouri et al., 2014). Kesalahan pada salah satu tahap akan menimbulkan kesalahan pada tahap selanjutnya.

\section{Metode}

Pencarian sumber dalam review ini dilakukan untuk mengambil referensi berupa jurnal ilmiah yang bekaitan dengan sumber data dalam medication errors. Adapun kriteria yang digunakan antara lain, jurnal ilmiah yang dimaksudkan merupakan naskah publikasi 7 tahun terkhir (tahun 2010-2017), memuat tema sumber data dalam medication errors secara detail dan merupakan jurnal ilmiah dengan publikasi nasional maupun internasional. Jumlah studi yang digunakan dalam review jurnal ini sebanyak 13 jurnal.

\section{Hasil dan pembahasan}

Medication error adalah suatu kejadian yang tidak hanya dapat merugikan pasien tetapi juga dapat membahayakan keselamatan pasien yang dilakukan oleh petugas kesehatan khususnya dalam hal pelayanan pengobatan pasien (NCCMERP, 2014). Salah satu faktor penyebab terjadinya ME adalah kegagalan komunikasi (salah interpretasi) antara prescriber (penulis resep) dengan dispenser (pembaca resep) (Rahmawati dan Oetari, 2002).

Penulisan resep yang lengkap membutuhkan pengetahuan yang menyeluruh dan pemahaman patofisiologi penyakit, serta sifat farmakologis obat yang relevan (Aronson, 2006).

Secara umum Medication error terdiri dari:

\section{Kesalahan Peresepan (prescribing error)}

Hal-hal yang sering terjadi prescribing error dari beberapa jurnal adalah penulisan resep yang sulit dibaca dibagian nama obat,, satuan numerik obat yang digunakan, bentuk sediaan yang dimaksud, tidak ada dosis sediaan, tidak ada umur pasien, tidak ada nama dokter, tidak ada SIP dokter, tidak ada tanggal pemberian (Rahmawati dan Oetari, 2002).

Tidak adanya bentuk sediaan ini sangat merugikan pasien. Pemilihan bentuk sediaan ini disesuaikan dengan kondisi pasien (Susanti, 2013). Dosis merupakan bagian yang sangat penting dalam resep. Tidak ada dosis sediaan berpeluang menimbulkan kesalahan oleh transcriber, hal ini karena beberapa obat memiliki dosis sediaan yang beragam (Chintia, 2016).

Pentingnya pencantuman berat badan dalam penulisan resep dikemukakan dalam penelitian Mamarimbing dkk., (2012), yang menyebutkan bahwa berat badan merupakan salah satu aspek penting yang diperlukan dalam perhitungan dosis, khususnya dosis anak. 
Pencantuman nama dan paraf dokter dalam resep juga merupakan hal yang penting untuk dicantumkan, jika terjadi kesalahan dalam hal peresepan maka petugas kefarmasian dapat langsung menghubungi dokter yang bersangkutan untuk melakukan verfikasi terkait dengan terapi obat yang diberikan kepada pasien (Akoria dan Isah, 2008), sedangkan pencantuman SIP dalam resep diperlukan untuk menjamin keamanan pasien, bahwa dokter tersebut mempunyai hak dan dilindungi undang-undang dalam memberikan terapi pengobatan kepada pasien (Mamarimbing dkk., 2012).

Pada penelitian yang dilakukan oleh Yosefin dkk (2016), bahwa faktor penyebab ME fase prescribing meliputi beban kerja yaitu rasio antara beban kerja dan SDM tidak seimbang, edukasi yaitu penulisan resep tidak memenuhi syarat kelengkapan resep, gangguan bekerja yaitu terganggu dengan dering telepon, kondisi lingkungan yaitu pencahayaan yang kurang mendukung saat bekerja, dan komunikasi yaitu permintaan obat secara lisan. Hal ini seharusnya bisa dihindari

\section{Kesalahan Penerjemahan Resep (transcribing erorr)}

Berdasarkan studi dokumentasi dari hasil laporan incident pada tahap prescribing dimana setelah resep di terima oleh unit farmasi rawat inap maka proses error yang terjadi adalah pada saat staf farmasi melakukan pembacaan resep dari prescriber (proses transcribing) (Putu N dkk, 2017).

Tipe-tipe trascribing errors antara lain (Ruchika Garg et al., 2014):

(a) Kelalaian, misalnya ketika obat diresepkan namun tidak diberikan. (b) Kesalahan interval, misalnya ketika dosis yang diperintahkan tidak pada waktu yang tepat. (c) Obat alternatif, misalnya pengobatan diganti oleh apoteker tanpa sepengetahuan dokter. (d) Kesalahan dosis, misalnya pada resep $0.125 \mathrm{mg}$ menjadi $0.25 \mathrm{mg}$ pada salinan. (e) Kesalahan rute, misalnya pada resep Ofloxacin tablet menjadi Ofloxacin I.V. (f) Kesalahan informasi detail pasien, meliputi nama, umur, gender, registrasi yang tidak ditulis atau salah ditulis pada lembar salinan.

\section{Kesalahan Menyiapkan dan Meracik Obat (dispensing error)}

Jenis kasus dispensing error yang terjadi pada layanan farmasi adalah salah obat, salah kekuatan obat, dan salah kuantitas. Hal ini selaras dengan beberapa penelitian lain antara lain Aldhwaihi et al (2016), dan James et al (2007). Salah obat adalah jenis error paling umum dari dispensing error pada pelayanan farmasi, sementara error lain adalah kekeliruan kekuatan obat (wrong medicine), dosis (wrong drug strength), dan jumlah obat (wrong quantity) (Aldhwaihi et al., 2016 dan James dkk, 2007) selaras dengan temuan penelitian tersebut (Pitoya Z. A. dkk, 2016). Ada juga rumah sakit dengan kejadian kekeliruan dosis angkanya jauh lebih banyak dari pada kekeliruan obat salah satunya adalah hasil penelitian Al-Khani S et al (2014). Penyebab tersebut bisa karena staf tidak mempunyai pengetahuan atau ketrampilan yang benar tentang berbagai ukuran dan ketrampilan kemampuan mengkonversi ke unit pengukuran lain. Hal ini sangat penting untuk mencegah kekeliruan dosis (Pitoya Z. A. dkk, 2016).

Pada penelitian yang dilakukan oleh Yosefin dkk (2016), bahwa faktor penyebab ME fase dispensing meliputi beban kerja yaitu rasio antara beban kerja dan SDM tidak seimbang, edukasi yaitu penyiapan obat yang tidak sesuai permintaan resep, komunikasi yaitu kurangnya komunikasi mengenai stok perbekalan farmasi, kondisi lingkungan yaitu tidak adanya ruangan penyiapan obat dan gangguan bekerja yaitu terganggu dengan dering telepon. 
Hal ini selaras dengan hasil penelitian Aldhwaihi et al (2016) yang menyimpulkan bahwa faktorfaktor yang berkaitan dengan dispensing errors adalah beban pekerjaan tinggi, jumlah staf yang kurang, obat LASA, kemasan yang mirip, sistem penyimpanan obat LASA dan gangguan lingkungan antara lain distraksi, interupsi.

\section{Kesalahan Penyerahan Obat Kepada Pasien (administration error)}

Kesalahan administrasi pengobatan (MAE) didefinisikan sebagai perbedaan antara apa yang diterima oleh pasien atau yang seharusnya diterima pasien dengan apa yang di maksudkan oleh penulis resep (Zed et al., 2008). MAE adalah salah satu area resiko praktik keperawatan dan terjadi ketika ada perbedaan antara obat yang diterima oleh pasien dan terapiobat yang ditunjukan oleh penulis resep (Williams, 2007).

Dari beberapa jurnal, jenis administration erorr yang terjadi pada saat pelayanan farmasi adalah kesalahan waktu pemberian obat, kesalahan teknik pemberian obat, dan obat tertukar pada pasien yang namanya sama (right drug for wrong patient). Salah satu contoh administration erorr, misalnya obat diberikan informasi diminum sesudah makan yang seharusnya sebelum makan atau yang seharusnya siang atau malam diberikan pagi hari. Contoh lain dokter menuliskan R/ Flunarizin $5 \mathrm{mg}$ signa $1 \times 1$ malam, Instalasi Farmasi memberikan Sinral $5 \mathrm{mg}$, tetapi perawat tidak mengetahui bahwa obat tersebut komposisinya sama dengan Flunarizin, mungkin juga karena kurang teliti, sampai terjadi pasien tidak diberikan obat karena di CPO ditulis Flunarizine $5 \mathrm{mg}$, signa $1 \times 1$ (Sarmalina dkk, 2011).

Faktor penyebab ME fase administration meliputi beban kerja yaitu rasio antara beban kerja dan SDM tidak seimbang, gangguan bekerja yaitu terganggu dengan dering telepon, edukasi yaitu tidak tepat waktu pemberian obat, kondisi lingkungan yaitu jarak unit farmasi tidak memudahkan tenaga kesehatan dalam pemberian obat dan komunikasi yaitu kurangnya komunikasi tenaga kesehatan dan pasien dalam penggunaan obat (Yosefin dkk, 2016).

Untuk menghindari kesalahan pengobatan, Apoteker dapat berperan nyata dalam pencegahan terjadinya kesalahan pengobatan melalui kolaborasi dengan dokter, pasien, serta tenaga kesehatan lainnya. Hal yang dapat dilakukan antara lain (Depkes RI, 2008) :

Identifikasi pasien minimal dengan dua identitas, misalnya nama dan nomor rekam medik/ nomor resep.

Apoteker tidak boleh membuat asumsi pada saat melakukan interpretasi resep dokter. Untuk mengklarifikasi ketidaktepatan atau ketidakjelasan resep, singkatan, hubungi dokter penulis resep.

Dapatkan informasi mengenai pasien sebagai petunjuk penting dalam pengambilan keputusan pemberian obat, seperti :

1) Data demografi (umur, berat badan, jenis kelamin) dan data klinis (alergi, diagnosis dan hamil/menyusui). Contohnya, Apoteker perlu mengetahui tinggi dan berat badan pasien yang menerima obat-obat dengan indeks terapi sempit untuk keperluan perhitungan dosis.

2) Hasil pemeriksaan pasien (fungsi organ, hasil laboratorium, tanda-tanda vital dan parameter lainnya). Contohnya, Apoteker harus mengetahui data laboratorium yang penting, terutama untuk obat-obat yang memerlukan penyesuaian dosis dosis (seperti pada penurunan fungsi ginjal). 
Apoteker harus membuat riwayat/catatan pengobatan pasien.

Strategi lain untuk mencegah kesalahan obat dapat dilakukan dengan penggunaan otomatisasi (automatic stop order), sistem komputerisasi (eprescribing) dan pencatatan pengobatan pasien seperti sudah disebutkan diatas.

Permintaan obat secara lisan hanya dapat dilayani dalam keadaan emergensi dan itupun harus dilakukan konfirmasi ulang untuk memastikan obat yang diminta benar, dengan mengeja nama obat serta memastikan dosisnya. Informasi obat yang penting harus diberikan kepada petugas yang meminta/menerima obat tersebut. Petugas yang menerima permintaan harus menulis dengan jelas instruksi lisan setelah mendapat konfirmasi.

\section{Kesimpulan}

Berdasarkan data yang dikumpulkan dari berbagai jurnal, prevalensi medication erorrs pada setiap tahapan yaitu prescribing, transcribing, dispensing, dan administration menunjukan hasil yang bervariatf di setiap tempat pelayanan farmasi atau instalasi farmasi. Hal ini dikarenakan, faktor penyebab terjadinya medication erorrs disetiap tempat berbeda-beda.

Penyebab medication error yang terjadi adalah adanya ketidaksesuaian penulisan instruksi di catatan medik dan di resep, tingginya beban kerja perawat, kurang adanya komunikasi yang baik antara dokter, perawat dan tenaga farmasi.

\section{Daftar Pustaka :}

Aldhwaihi K, Schifano F, Pezzolesi C, and Umaru N. 2016. Systematic Review of the Nature of Dispensing Errors in Hospital Pharmacies. Integrated Pharmacy Research and Practice 5: 1-10.

Al-Khani S, Moharram A, and Aljadhey H. 2014. Factors Contributing to the Identification and Prevention of Incorrect Drug Prescribing Errors in Outpatient Setting. Saudi Pharmaceutical Journal 22(5):429-432.

Chintia Timbongol, Widya Astuty L, Sri Sudewi. 2016. Identifikasi Kesalahan Pengobatan (Medication Error) pada Tahap Peresepan (Prescribing) Di Poli Interna RSUD Bitung. Pharmacon 5(3):1-6 ISSN $2302-2493$.

Hartati, Nike Herpianti Lolok, Achmad Fudholi, Satibi. 2014. Analisis Kejadian Medication Error pada Pasien ICU. Jurnal Manajemen dan Pelayanan Farmasi 4 (2):125-132.

Khodir Abdul Jaelani, Findy Hindratni. 2017. Gambaran Skrining Resep Pasien Rawat Jalan Di Puskesmas Kota Yogyakarta Tahun 2015. Journal Endurance 2 (1): 1-6.

Horri et al. 2014. Frequency of dosage prescribing medication errors associated with manual prescriptions for very preterm infants. Journal of Clinical Pharmacy and Therapeutics 39, 637-64

Nilasari Putu, Delina Hasan, Wahyudi Uun H. 2017. Faktor-Faktor yang Berkaitan/ Berhubungan dengan Medication Error dan Pengaruhnya Terhadap Patient Safety yang Rawat Inap di RS. Pondok Indah Jakarta Tahun 2012 - 2015. Social Clinical Pharmacy Indonesia Journal 2 (1):1-9 ISSN 2502-8413. 
Pitoyo A Zani, Tuti Hariyanto, Navis Yuliansyah, Indah Mauludiyah. 2016. Kebijakan Sistem Penyimpanan Obat LASA, Alur Layanan, dan Formulir untuk Mencegah Dispensing Error. JK Brawijaya 29 (3):235-244.

Sarmalina S, Paryanti, Sonlimar M. 2011. Pengaruh Partisipasi Tenaga Teknis Kefarmasian dalam Menurunkan Angka Kejadian Medication Error di Bangsal Penyakit Dalam RS RK Charitas Palembang. Majalah Kesehatan PharmaMedika 3 (1):211-216.

Senafikish Amsalu F, Muluadam Abebe M, Yeshaneh Seyoum Y. 2015. Medication Administration error: Magnitude and Associated Factors Among Nurses in Ethiopia. BMC Nurs 14:53

Tien Wahyu Handayani. 2017. Faktor Penyebab Medication Error di RSU Anutapura Kota Palu. Jurnal Pengembangan Sumber Daya Insani 2(2):224-229.

Yosefin Ch. D, Heedy Tjitrosantoso, Widdhi Bodhi. 2016. Faktor Penyebab Medication Error pada Pelayanan Kefarmasian Rawat Inap Bangsal Anak RSUP Prof. DR. R.D. Kandou Manado. Pharmacon 5 (3):66-74 ISSN 2302 - 2493.

Zakiah Rasmi O, Zahra Wafiyatunisa. 2017. Kejadian Medication Error Pada Fase Prescribing Di Poliklinik Pasien Rawat Jalan RSD Mayjend HM Ryacudu Kotabumi. JK Unila 1 (3):540-545. 